\title{
Dyckia tubifilamentosa (Pitcairnioideae-Bromeliaceae): a new species from Northeastern Brazil
}

\author{
Maria das Graças Lapa Wanderley ${ }^{1,4}$, Gardene Maria de Sousa ${ }^{2}$ and Marccus Alves ${ }^{3}$
}

Received: 27.03.2014; accepted: 30.05.2014

\begin{abstract}
Dyckia tubifilamentosa (Pitcairnioideae-Bromeliaceae): a new species from Northeastern Brazil). Dyckia tubifilamentosa Wand. \& G. Sousa is described and illustrated. It differs from the other species of the genus Dyckia by several distinctive characters, namely: the ovoid shape of the flower buds, the long and exserted staminal tube formed from completely connate white filaments, the anther initially connivent and then divergent, along with the fruit with partially persistent perianth. Dyckia tubifilamentosa is found in some areas of the semiarid region of Northeastern Brazil (Piauí State), growing in the Caatinga and transitional Caatinga-Cerrado biomes.
\end{abstract}

Keywords: Caatinga, neotropics, semiarid

RESUMO - (Dyckia tubifilamentosa (Pitcairnioideae-Bromeliaceae): uma nova espécie do Nordeste do Brasil). Dyckia tubifilamentosa Wand. \& G. Sousa é aqui descrita e ilustrada. A espécie se distingue das demais do gênero Dyckia pelo botão floral ovoide; tubo estaminal exserto e esbranquiçado, formado pelos filetes completamente conados; anteras coniventes passando a divergentes e fruto com restos de perianto. Dyckia tubifilamentosa é conhecida de algumas áreas da região semiárida do Nordeste do Brasil (estado do Piauí), crescendo na Caatinga e áreas de transição Caatinga-Cerrado.

Palavras-chave: Caatinga, neotrópicos, semiárido

Bromeliaceae comprises 43 genera and 1290 species in Brazil (Forzza et al. 2014), which represents almost $40 \%$ of the family's diversity. This family is found in all Brazilian ecosystems and is very common in the humid coastal forest region (Atlantic Forest) and in the Cerrado vegetation, especially on rocky outcrops.

Bromeliaceae has also been regarded by AndradeLima (1957) as one of the typical floristic components of the Brazilian semiarid vegetation, the so-called Caatinga (deciduous forest). This ecosystem combines different vegetation types throughout most of the semiarid region in Northeastern Brazil (Rodal \& Sampaio 2002). Around 123 species of the family distributed in 30 genera have been cited for Caatinga by Forzza et al. (2014), of which the most common ones are: Neoglaziovia variegata (Arruda) Mez, Bromelia laciniosa Mart. ex Schult. \& Schult. f., Dyckia limae L.B. Sm., D. pernambucana L.B. Sm. and Encholirium spectabile Mart. ex Schult. \&
Schult. f. (Wanderley \& Sousa 2002, Wanderley et al. 2009).

Very recently, terrestrial and rupicolous specimens of a taxon distinct from the previously described species of Dyckia were collected in the State of Piauí and are described herewith as a new species. The flower buds are greenish and ovoid, having a long exserted staminal tube, most of the ovary's length is above the petals and sepals; the fruits are capsular with winged seeds.

Dyckia tubifilamentosa Wand. \& G. Sousa, $s p$. nov. - Type: BRAZIL. PIAuí: Município de Pedro II, estrada Pedro II a Domingos Mourão (04³0'31"S, $\left.41^{\circ} 19^{\prime} 98^{\prime \prime} \mathrm{W}\right)$, cerca de $69 \mathrm{~km}$ do centro de Pedro II, 13-III-2008, fl., fr., M.G.L. Wanderley, G. Sousa \& R. Barros 2630 (holotypus SP, isotypus TEPB). (figures: 1-2).

Dyckia tubifilamentosa is easily distinguished from the other species of Dyckia by the ovoid shape

1. Instituto de Botânica de São Paulo, Núcleo de Pesquisa Curadoria do Herbário, Av. Miguel Estéfano 3687, 04301-012 São Paulo, SP, Brazil

2. Universidade Federal do Piaú, Departamento de Biologia, Campus Ministro Petrônio Portela, 64049-550 Teresina, PI, Brazil

3. Universidade Federal de Pernambuco, Departamento de Botânica, Av. Moraes Rego s/n, 50630-970 Recife, PE, Brazil

4. Corresponding author: gracaw@me.com 


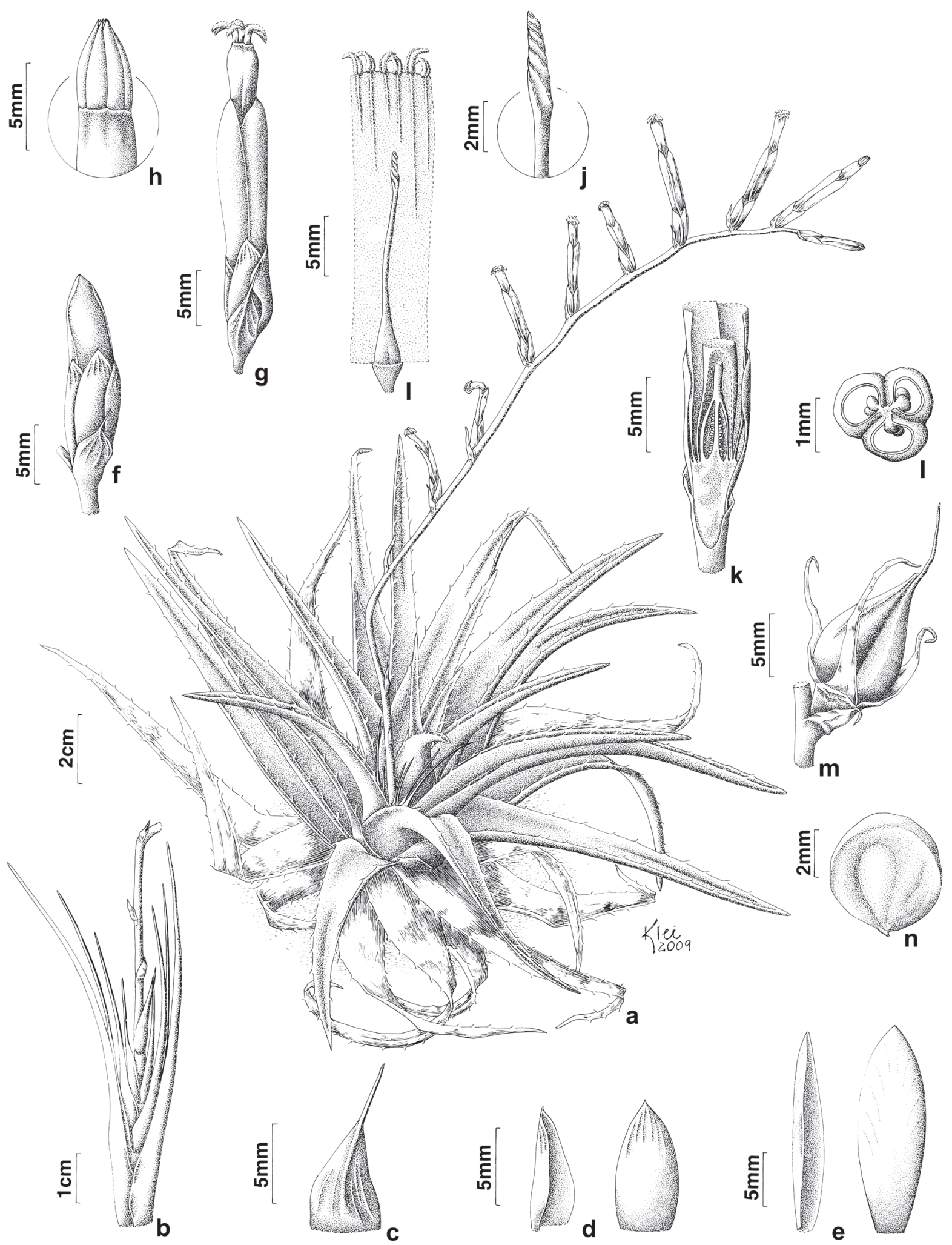

Figure. 1. Dyckia tubifilamentosa Wand. \& G. Sousa (from the holotype). a. Habit. b. Detail of the base of the peduncle. c. Floral bract. d. Sepals. e. Petals. f. Floral bud. g. Flower with the long staminal tube. h. Anthers at pre-anthesis. i. Detail of the gynoecium with the staminal tube longitudinally sectioned. j. Spirally conduplicate stigma. k. Longitudinal section of the base of the flower with a detail of the vestigial tube and the superior ovary. 1 . Transversal section of the ovary. m. Fruit. n. Seed. 
of the flower buds, a long and exserted staminal tube formed from completely connate filaments which become vinaceous to purplish at post-anthesis; anthers are initially connivent and then divergent and the perianth is partially persistent in the fruit. This combination of characters is a distinctive and unusual set of diagnostic characters within the genus.

Herbaceous plants, terrestrial or rupicolous, growing usually in small clumps or as isolated individuals, $22-58 \mathrm{~cm}$ tall when in bloom. Roots thick. Rhizome contracted and covered by leaf sheaths. Rosette with strongly imbricate leaves, straight to curved, distichous or secund. Leaves 13-17 cm long; sheath 2-2.5 × 3-4 cm, sheath broad, oval, fleshy, whitish to greenish, margins entire, blade $11-14.5 \mathrm{~cm}$ long, narrowly triangular, green, brownish to vinaceous, cinereous lepidote, apex mucronate, margins strongly spiny, spines 1-2 mm long, brown and brittle, erect or retrorse in the upper portion of the blade. Peduncle lateral, $10-50 \times 0.2 \mathrm{~cm}$, glabrous, green to vinaceous, basal bracts numerous and overlapping each other, foliaceous, $6-9 \times 0.2 \mathrm{~cm}$ and exceeding the internodes, narrowly triangular, creamy-green, apex attenuate, margins entire, keeled, the remaining peduncle bracts $0.2 \times 0.8-2.0 \mathrm{~cm}$ and shorter than the internodes, ovate to filiform, reddish-brown with attenuate apex, margins entire. Inflorescence spicate, with 2-10 flowers, sparsely arranged, secund, rarely distichous; rachis slender, slightly geniculate. Flowers 2.8-3.2 cm long, sessile to subsessile, aestivation imbricate; buds yellowish to greenish, ovoid. Floral bracts 3-5 $\mathrm{mm}$ long, ovate, green to reddish-brown, apex caudate, margins entire. Sepals connate at the base, 0.8-1.1 cm long, symmetrical, ovate, apex apiculate, green with translucent dots and dark-reddish wrinkles at the base, veins slightly visible at the apex, margins entire. Petals free, naked, 1.7-2 cm long, oblong-lanceolate, slightly cucullate, green or with dark-reddish wrinkles at the apex, apex acute, margins entire. Androecium 2-2.8 cm long, filaments entirely connate, filament tube $2-2.3 \mathrm{~cm}$ long, white becoming vinaceous to purplish, exserted, anthers sub-basifixed, 0.5-0.6 cm long, sagittiform, creamy yellow, connivent, divergent in post-anthesis, pollen grains monosulcate, ellipsoidal, exine reticulate. Gynoecium ca. $2.2 \mathrm{~cm}$ long, included in the filament tube, stigma lobes laminar, spirally-conduplicate; ovary superior, ca. $1 \mathrm{~cm}$ long; placentation axial, ovules numerous, located in the lower third. Capsule loculicidal and also septicidal in the upper third, $1.4 \times 0.9 \mathrm{~cm}$, ovoid, brown, perianth partially persistent. Seeds $4.2 \times 2.5 \mathrm{~mm}$, ovoid, round-ovoid to falciform, wings corky, light to dark-brown.

Etymology: The epithet refers to the long staminal tube.

Habitat: Heliophilous plants growing on rocky soils or on rock outcrops in the Caatinga vegetation (figure $2 \mathrm{a}$ ) as well as in areas considered transitional to the Cerrado biome in the State of Piauí, Northeastern Brazil.

Additional material examined (paratypes): BRAZIL. Piaui: Campo Maior, Serra de Santo Antonio, 045' 21 "S 42¹0'16"W, 28-I-2008, fl., fr., Sousa \&

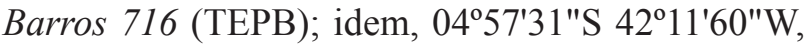
13-III-2008, fl., Wanderley et al. 2625 (SP, TEPB); Serra do Bugari, 6-III-2010, Castro 2303 (EAC).

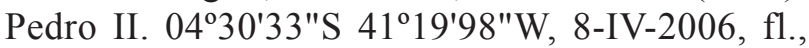
Barros et al. 2764 (TEPB); Malhada da Areia, 0430'317"S 41ำ19'98"W, 27-I-2008, fl., fr., Sousa 713 (TEPB); idem, 13-III-2012, fr., Sousa et al. 718 (TEPB).

Dyckia tubifilamentosa can be ascribed to the Pitcairnioideae subfamily by the terrestrial or rupicolous habit (figures $2 \mathrm{a}-\mathrm{c}$ ), leaves with spiny margins (figure $1 \mathrm{a}$ ) and capsular fruits with winged seeds (figures $1 \mathrm{~m}, \mathrm{n}$ ) which are common features in most genera of the subfamily. The characteristics are the same as those used in the circumscription of Pitcairnioideae, both in the wide sense (Smith \& Downs 1974) or under the new concept (Pitcairnioideae s. str.) adopted by Givnish et al. (2011).

This new species has lateral inflorescences (figures $1 \mathrm{a}, 2 \mathrm{c}$ ), a common character in most species of Dyckia. However, it differs from the other species of the genus by many distinctive characters, namely: the ovoid flower buds (figures $1 \mathrm{f}, 2 \mathrm{~d}$ ), the long exserted staminal tube formed by completely connate white filaments which become vinaceous to purplish after the anthesis (figures $1 \mathrm{a}, \mathrm{g}, 2 \mathrm{e}-\mathrm{g}$ ), the initially connivent then divergent and persistent anthers (figures $1 \mathrm{~g}, \mathrm{~h}$, $2 \mathrm{e}-\mathrm{g}$ ) and the fruit with partially persistent perianth and gynoecium. These combined features are good and unusual diagnostic characters in the genus.

Dyckia usually presents either orange or red to yellow petal with stamens adnate to the petals or to the sepals forming a common ring, erect and narrow to compact stigma lobes (Forzza \& Wanderley 1998, Forzza 2005). The staminal tube in Dyckia is often short, and when longer it never exceeds the corolla (Smith \& Downs 1974). Dyckia tubifilamentosa 
also has oblong-lanceolate petals, whereas often in Dyckia they are ovate to obovate. These characters, observed in the new species, are considered part of the morphological character variation of Dyckia, thus widening the morphological circumscription of the genus.

Dyckia is morphologically related to Encholirium, especially because both genera share the presence of naked petals. They can usually be distinguished by the lateral inflorescences and adnate filaments in Dyckia, while Encholirium often has a terminal inflorescence and free filaments. The weak delimitation between these two genera can be seen in certain intermediate species of each genus which show overlapping characters. Dyckia tubifilamentosa resembles Encholirium in its elongate and spirally conduplicate stigma lobes and green sepals and petals, however, the new species is easily distinguished from all species of Encholirium by its lateral scape and staminal tube, absent in Encholirium and present in almost all species of Dyckia.

Smith \& Downs (1974) characterized the genera of the Pitcairnioideae s.l. by the position of the ovary, as for example, by an entirely superior ovary (Encholirium) or a partially or entirely inferior one (Dyckia). However, ovary position is not as consistent as previously assumed within the genera of Pitcairnioideae. Bernardello et al. (1991) and
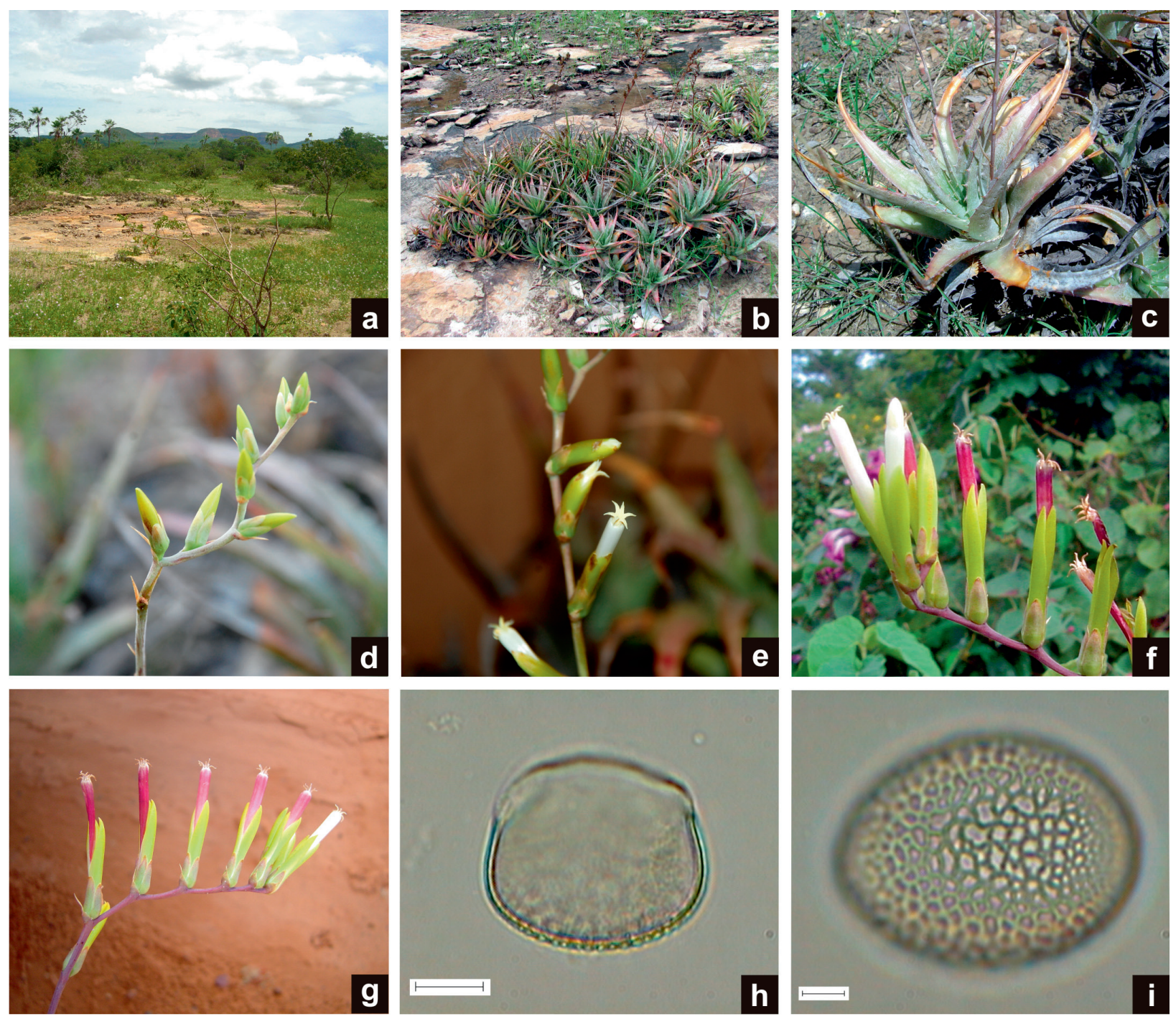

Figure 2. Dyckia tubifilamentosa Wand. \& G. Sousa (from the holotype). a. General view of the area of occurrence in Piauí State, Northeastern Brazil. b. Habit. c. Detail of the rosette with a lateral peduncle. d. Immature inflorescence with yellowish flower buds. e. Inflorescence showing buds and open flowers with a whitish and long staminal tube and divergent anthers. f. Inflorescence with flowers with whitish and long staminal tube and flowers with reddish tube at post-anthesis. g. Inflorescence showing secund flowers. h-i . Pollen grains (Sousa et al. 713). h. Equatorial view showing the monosulcate aperture. i. Polar view, detail of the reticulate exine. (scales bar: $\mathrm{h}=10 \mu \mathrm{m} ; \mathrm{i}=5 \mu \mathrm{m})$. 
Forzza (2005) reported perigynous flowers with a short epigynous tube in Encholirium. In Dyckia tubifilamentosa, the occurrence of perigynous flowers was not confirmed, but an inconspicuous tube can be seen (figure $1 \mathrm{k}$ ). The capsular fruit (figure $1 \mathrm{~m}$ ) and the appendaged seeds (figure $1 \mathrm{n}$ ) found in D. tubifilamentosa are also described within the Pitcairnioideae both in the wide or strict senses (Smith \& Downs 1974, Givnish et al. 2011).

The distinctive and unusual combination of characters in Dyckia tubifilamentosa led us initially to consider proposing a new genus. Therefore, considering the weak delimitation of related genera of Pitcairnioideae s.l., emphasized by Krapp et al. (2014), we have decided to describe this new species under Dyckia, with which it shares some diagnostic characters (lateral inflorescence and connate filaments) and similar pollen morphology, with monosulcate pollen and reticulate exine (figures $2 \mathrm{~h}$, i).

\section{Acknowledgements}

The authors wish to thank R. Barros and F. Oliveira for their support in sample collection. We also would like to thank K. Sousa for the illustrations. Financial support: M.G.L. Wanderley and G.M. Sousa (FAPEPI, CAPESPNADB, CNPq, REFLORA-563858/2010-5).

\section{Literature cited}

Andrade-Lima, D. 1957. Estudos fitogeográficos de Pernambuco. Secretaria de Agricultura, Indústria e Comércio, Instituto de Pesquisas Agronômicas de Pernambuco, Recife.

Bernardello, M., Galleto, L. \& Juliani, H. 1991. Floral nectar, nectary structure and pollinators in some Argentinean Bromeliaceae. Annals of Botany 67: 401-411.

Forzza, R.C. 2005. Revisão Taxonômica de Encholirium Mart. ex Schult. \& Schult. f. (Pitcairnoideae Bromeliaceae). Boletim de Botânica da Universidade de São Paulo 23: 1-49.
Forzza, R. \& Wanderley, M.G.L. 1998. Flora da Serra do Cipó, Minas Gerais: Bromeliaceae - Pitcairnioideae. Boletim de Botânica da Universidade de São Paulo 17: 225-270.

Forzza, R.C., Costa, A., Siqueira Filho, J.A., Martinelli, G., Monteiro, R.F., Santos-Silva, F., Saraiva, D.P. \& Paixão-Souza, B. 2014. Bromeliaceae. In: Lista de Espécies da Flora do Brasil. Jardim Botânico do Rio de Janeiro, Rio de Janeiro. http://floradobrasil.jbrj.gov. br/2012/FB000066 (access in 1-II-2014).

Givnish,T.J., Barfuss, M.H.J., Van Ee, B., Riina, R., Schulte, K., Horres, R., Gonsiska, P.A., Jabaily, R.S., Crayn, D.M., Smith, J.A.C., Winter, K., Brown, G.K., Evans, T.M., Holst, B.K., Luther, H., Till, W., Zizka, G., Berry, P.E. \& Sytsma, K.,J. 2011. Phylogeny, adaptive radiation, and historical biogeography in Bromeliaceae: Insights from an eight-locus plastid. American Journal of Botany 98: 1-24.

Krapp, F., Pinange, D., Benko-Iseppon, A., Leme, L. \& Weising, K. 2014. Phylogeny and evolution of Dyckia (Bromeliaceae) inferred from chloroplast and nuclear sequences. Plant Systematics and Evolution DOI 10.1007/s00606-014-0985-0.

Rodal, M.J.N. \& Sampaio, E.V. 2002. A vegetação do Bioma Caatinga. In: E.V. Sampaio, A.M. Giulietti, J. Virgínio \& C. Gamarra-Rojas (orgs.). Vegetação e Flora da Caatinga. Associação Plantas do Nordeste, Recife, pp. 11-24.

Smith, L.B. \& Downs, R.J. 1974. Pitcairnioideae (Bromeliaceae). Flora Neotropica Monograph 14: 1-658.

Wanderley, M.G.L. \& Sousa, G.M. 2002. Distribuição das espécies de Bromeliaceae na caatinga. In: E.V. Sampaio, A.M. Giulietti, J. Virgínio \& C. Gamarra-Rojas (orgs.). Vegetação e Flora da Caatinga. Associação Plantas do Nordeste, Recife, pp. 121-122.

Wanderley, M.G.L., Louzada, R.B., Sousa, G.M., Lima, T.T. \& Versieux, L.M. 2009. Catálogo de plantas raras do Brasil: Bromeliaceae. In: A. Giulietti, A. Rapini, M. Andrade, L. Queiroz \& J. Silva (orgs.). Plantas raras do Brasil. Conservação Internacional, Belo Horizonte, pp. 103-114. 